\title{
Zirconium phosphate protonic conductor obtained by sonocatalytic sol- gel method
}

\author{
M. ATIK, A. PAWLICKA, M. A. AEGERTER \\ Departamento de Física e Ciência dos Materiais, Instituto de Física de São Carlos, Universidade de São Paulo, C.P. \\ 369 CEP 13560-970 São Carlos (S.P) Brazil
}

The sol-gel process is an interesting alternative to produce gels, ceramics, glasses, thin films and fibres [1-4] which are difficult to prepare or could not be prepared by conventional methods. This technique is an excellent preparative route to synthesize materials such as zirconium phosphate through hydrolysis and polycondensation reactions of metal alkoxide. We have used the sol-gel method with application of ultrasound in the preparation of $\alpha-\mathrm{Zr}\left(\mathrm{HPO}_{4}\right)_{2} \mathrm{H}_{2} \mathrm{O}$ gels. This material was initially known as an inorganic ion exchanger and was of interest as a solid state electrolyte for use in fuel cell and alternative energy sources $[5,6]$. The electrical transport property of $\alpha-\mathrm{Zr}\left(\mathrm{HPO}_{4}\right)_{2} \mathrm{H}_{2} \mathrm{O}$ is due to diffusion of protons along the hydrated surface of their microcrystalline structure, and depends essentially on the number of surface ionogenic groups [7], particle dimensions [8] and their hydration [9].

In this work, we discuss the preparation of zirconium phosphate gels obtained by a sonocatalytic route and their characterization by thermal analysis (TG, DTA, DSC), X-ray diffraction (XRD), infrared spectroscopy (IRS) and scanning electron microscopy (SEM). The ionic conductivity of the samples was studied between 50 and $350^{\circ} \mathrm{C}$ by a.c. impedance spectroscopy.

Zirconium phosphate gels $\alpha-\mathrm{Zr}\left(\mathrm{HPO}_{4}\right)_{2} \mathrm{H}_{2} \mathrm{O}$ (denominated as $\alpha$-ZrP) were prepared by hydrolysis and polycondensation reactions of zirconium propoxide $\mathrm{Zr}\left(\mathrm{OC}_{3} \mathrm{H}_{7}\right)_{4}$ diluted in isopropanol $\mathrm{C}_{3} \mathrm{H}_{7} \mathrm{OH}$, to which phosphoric acid $\mathrm{H}_{3} \mathrm{PO}_{4}$ and water were added. The volume ratios $\mathrm{Zr}\left(\mathrm{OC}_{3} \mathrm{H}_{7}\right)_{4} / \mathrm{C}_{3} \mathrm{H}_{7} \mathrm{OH}$, $\mathrm{H}_{2} \mathrm{O} / \mathrm{C}_{3} \mathrm{H}_{7} \mathrm{OH}$ and $\mathrm{H}_{2} \mathrm{O} / \mathrm{H}_{3} \mathrm{PO}_{4}$ were equal to 1,2 and 4 , respectively. The technique consists in submitting the solution mixture to the action of ultrasonic irradiation (Sonicator W385 Heat SystemsUltrasonics, Inc., $20 \mathrm{kHz}$ ) [10-13]. After $25 \mathrm{~min}$, the liquid became homogeneous and white. The resulting sols were kept in a closed vessel and left at room temperature until forming gels. The gels were then dried at $50{ }^{\circ} \mathrm{C}$ for 1 week.

Thermal analysis (DTA-TG) and (DSC) were performed with a Netzsch STA 409 and a General V4.1C DuPont 2000 instruments, respectively, in an oxygen atmosphere at a heating rate of $10^{\circ} \mathrm{C} / \mathrm{min}$.

$\mathrm{X}$-ray powder diffraction patterns were obtained with a Rigaku-Rotaflex $\mathrm{Ru} 200 \mathrm{~B}$ diffractometer using monochromatic $\mathrm{CuK}_{\alpha}$ radiation of wavelength $0.15418 \mathrm{~nm}$.
IR spectra were obtained using the $\mathrm{KBr}$ disk method with a FTIR Bomem MB-102 operating between 400 and $4000 \mathrm{~cm}^{-1}$ and the SEM analysis was performed with a Zeiss 960 microscope.

Gel pellets of $10 \mathrm{~mm}$ in diameter and $1.5-2 \mathrm{~mm}$ thick, with bulk densities of about $80 \%$ of the theoretical value, were prepared by uniaxial pressing a suitable amount of $\alpha-\mathrm{Zr}\left(\mathrm{HPO}_{4}\right)_{2} \mathrm{H}_{2} \mathrm{O}$ gels at $60 \mathrm{kN} /$ $\mathrm{cm}^{2}$ in order to perform a.c. impedance analysis. The two flat surfaces of the pellet were coated with silver paint and the a.c. measurements of samples were carried out with a Solartron 1260 impedance analyser in the frequency range $10 \mathrm{~Hz}-10 \mathrm{MHz}$, at a signal level lower than $1 \mathrm{~V}$ using a home-made furnace temperature controller.

The DTA curve shows two superimposed endothermic peaks at $130^{\circ} \mathrm{C}$ and $153^{\circ} \mathrm{C}$ due to the loss of the hydration water; the third peak at $246{ }^{\circ} \mathrm{C}$ can be associated to the formation of a layered pyrophosphate structure of zirconium, and the complete conversion to $\mathrm{ZrP}_{2} \mathrm{O}_{7}$ was observed between 500 and $750^{\circ} \mathrm{C}$ (Fig. 1).

The TG curve (Fig. 1) shows a small difference between the losses of hydration and $\mathrm{POH}$ condensation water occuring at about $250^{\circ} \mathrm{C}$. This water loss is the result of condensation of monohydrogen phosphate groups to form the layered pyrophosphate.

The DSC curve (Fig. 2) confirms the DTA thermal analysis and shows two endothermic peaks at $138^{\circ} \mathrm{C}$ and $150^{\circ} \mathrm{C}$ associated with the hydration water loss

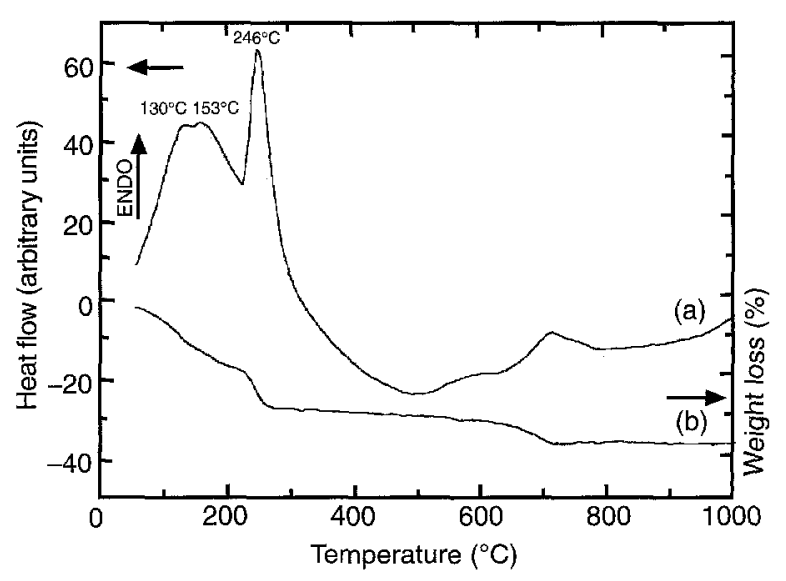

Figure 1 (a) DTA and (b) TG curves for $\alpha-\mathrm{Zr}\left(\mathrm{HPO}_{4}\right)_{2} \mathrm{H}_{2} \mathrm{O}$ gels at a heating rate of $10^{\circ} \mathrm{C} / \mathrm{min}$. 


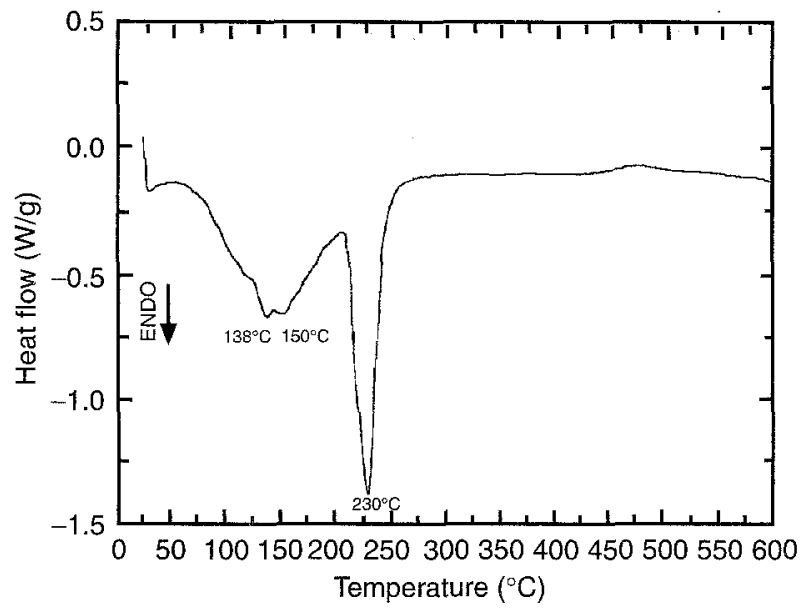

Figure 2 DSC curve of $\alpha-\mathrm{Zr}\left(\mathrm{HPO}_{4}\right)_{2} \mathrm{H}_{2} \mathrm{O}$ dried gels. The heating rate is $10^{\circ} \mathrm{C} / \mathrm{min}$.

and a third at $230{ }^{\circ} \mathrm{C}$ with the phase transition to pyrophosphate structure.

At room temperature, the X-ray patterns of $\alpha$ - $\mathrm{ZrP}$ gels showed good crystallinity, as can be seen in Fig. 3a. The diffraction patterns present peaks with $d$ values of $0.768,0.450,0.358$ and $0.264 \mathrm{~nm}$ corresponding to the $\alpha$-structure of monohydrated zirconium phosphate. After heat treatment at $200{ }^{\circ} \mathrm{C}$ (Fig. $3 \mathrm{~b})$, the crystalline structure of $\alpha-\mathrm{Zr}-\left(\mathrm{HPO}_{4}\right)_{2}$ $\mathrm{H}_{2} \mathrm{O}$ changes to the layered pyrophosphate structure which is maintained until $700^{\circ} \mathrm{C}$ (Fig. 3c, 3d). The $\mathrm{X}$-ray diffractograms of pyrophosphate show peaks which appear at $d=0.499,0.429,0.382,0.347$, $0.299,0.254,0.187$ and $0.161 \mathrm{~nm}$.

The IR spectra (Fig. 4) show the evolution of $\mathrm{Zr}\left(\mathrm{HPO}_{4}\right)_{2} \mathrm{H}_{2} \mathrm{O}$ heat treated at different temperatures. According to Clearfield [14] the sharp bands in the region $3150-3590 \mathrm{~cm}^{-1}$ are attributed to symmetric and asymmetric water stretching while the one at $1620 \mathrm{~cm}^{-1}$ is the bending vibration. The bands attributed to water are largely removed upon dehydration at $100^{\circ} \mathrm{C}$. The bands in the region $965-1120 \mathrm{~cm}^{-1}$ represent phosphate vibration and at $1250 \mathrm{~cm}^{-1}$ the deformation of the $\mathrm{P}-\mathrm{O}-\mathrm{H}$ group. The

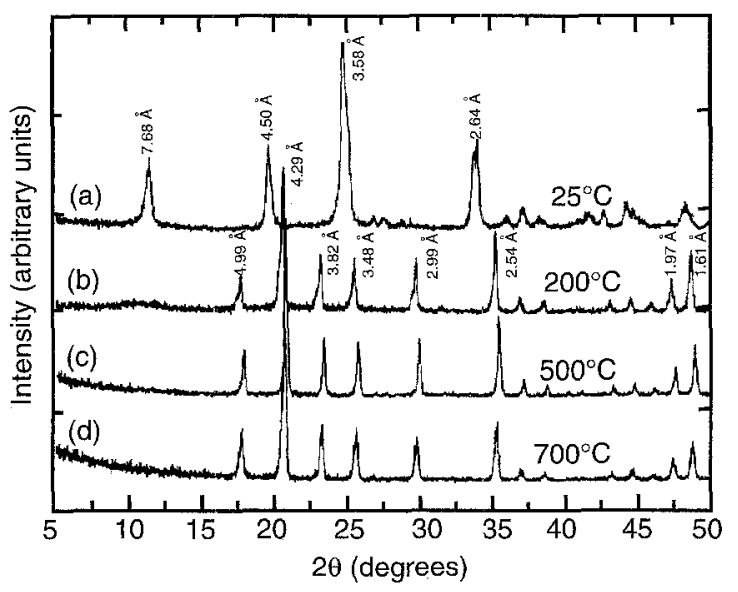

Figure $3 \mathrm{X}$-ray diffraction patterns of $\alpha-\mathrm{ZrP}$ as a function of temperature: (a) $25{ }^{\circ} \mathrm{C}$, (b) $200{ }^{\circ} \mathrm{C}$; (c) $500{ }^{\circ} \mathrm{C}$; (d) $700{ }^{\circ} \mathrm{C}$.

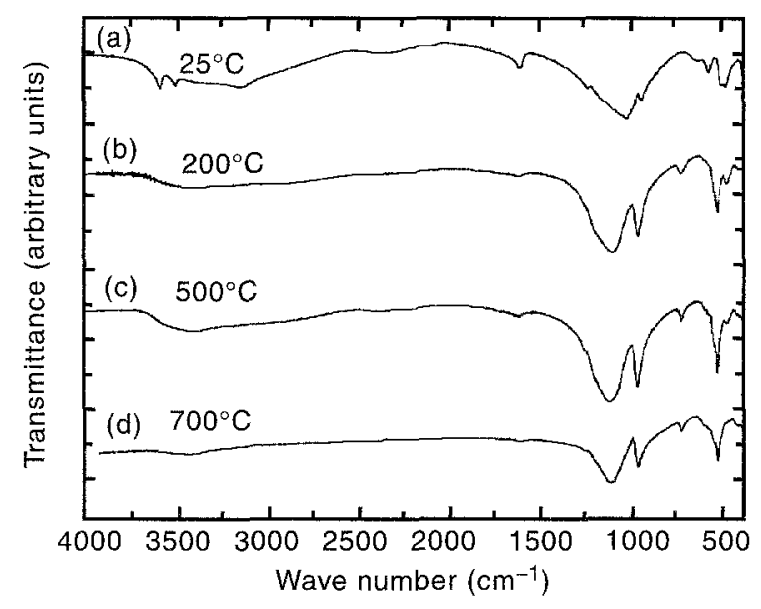

Figure 4 FTIR spectra of $\alpha$ - ZrP heat treated at different temperatures: (a) $25^{\circ} \mathrm{C}$, (b) $200^{\circ} \mathrm{C}$; (c) $500{ }^{\circ} \mathrm{C}$; (d) $700{ }^{\circ} \mathrm{C}$.

crystalline $\mathrm{Zr}\left(\mathrm{HPO}_{4}\right)_{2} \mathrm{H}_{2} \mathrm{O}$ treated at $200^{\circ} \mathrm{C}$ shows four bands at $548 \mathrm{~cm}^{-1}$ attributed to $\mathrm{Zr}-\mathrm{O}$ group, $747 \mathrm{~cm}^{-1}$ to $\mathrm{Zr}-\mathrm{O}-\mathrm{P}$ group, $977 \mathrm{~cm}^{-1}$ to $\mathrm{P}-\mathrm{O}$ group and $1131 \mathrm{~cm}^{-1}$ to $\mathrm{P}-\mathrm{O}$ group, respectively.

The electron microscopy micrographs (Fig. 5a, 5b) show the resultant morphology of $\alpha$ - $\mathrm{ZrP}$ xerogels heat treated at $150^{\circ} \mathrm{C}$ for $2 \mathrm{~h}$. The structure of the gel is formed by uniform aggregates of particles with average size of about $150 \mathrm{~nm}$. When the samples are heat treated at $400{ }^{\circ} \mathrm{C}$ for $2 \mathrm{~h}$, no change was observed (Fig. 5c, 5d).

The a.c. conductivity measurements were performed as a function of temperature in the range $50-350{ }^{\circ} \mathrm{C}$ (Fig. 6) in air. The conductivity of the $\alpha$ $\mathrm{Zr}\left(\mathrm{HPO}_{4}\right)_{2} \mathrm{H}_{2} \mathrm{O}$ increases from a value of $2.75 \times 10^{-4} \Omega^{-1} \mathrm{~cm}^{-1}$ at $50{ }^{\circ} \mathrm{C}$ to $4.25 \times 10^{-4} \Omega^{-1}$ $\mathrm{cm}^{-1}$ at $180^{\circ} \mathrm{C}$. For temperatures higher than $180^{\circ} \mathrm{C}$, conductivity decreases as a result of the dehydration of the sample and formation of pyrophosphate $\mathrm{ZrP}_{2} \mathrm{O}_{7}$ in accordance with the X-ray analysis, which shows a conversion to zirconium pyrophosphate at temperature $200^{\circ} \mathrm{C}$. We believe that the dehydration process is responsible for the loss in conductivity.

$\alpha$-zirconium phosphate with surface proton conductor can be easily obtained using a solution of organo-metallic precursors and phosphoric acid with the application of ultrasonic treatment; the material can be converted upon heat treatment to a pyrophosphate form. The investigation of the a.c. conductivity of the samples performed over the range $50-350{ }^{\circ} \mathrm{C}$ indicates that the protonic conductivity of samples increases with temperature up to a value $4.25 \times 10^{-4} \mathrm{~S} \mathrm{~cm}^{-1}$ and then decreases. $\alpha-\mathrm{Zr}$ $\left(\mathrm{HPO}_{4}\right)_{2} \mathrm{H}_{2} \mathrm{O}$ has the highest protonic conductivity at $180^{\circ} \mathrm{C}$.

\section{Acknowledgements}

The authors are indebted to E. Pereira and L. O. S. Bulhões (UFSCar) for assistance with the conductivity measurements. This research was sponsored by CNPq, FAPESP, FINEP, CAPES/PICD and the Program RHAE-Novos Materiais (Brazil). 

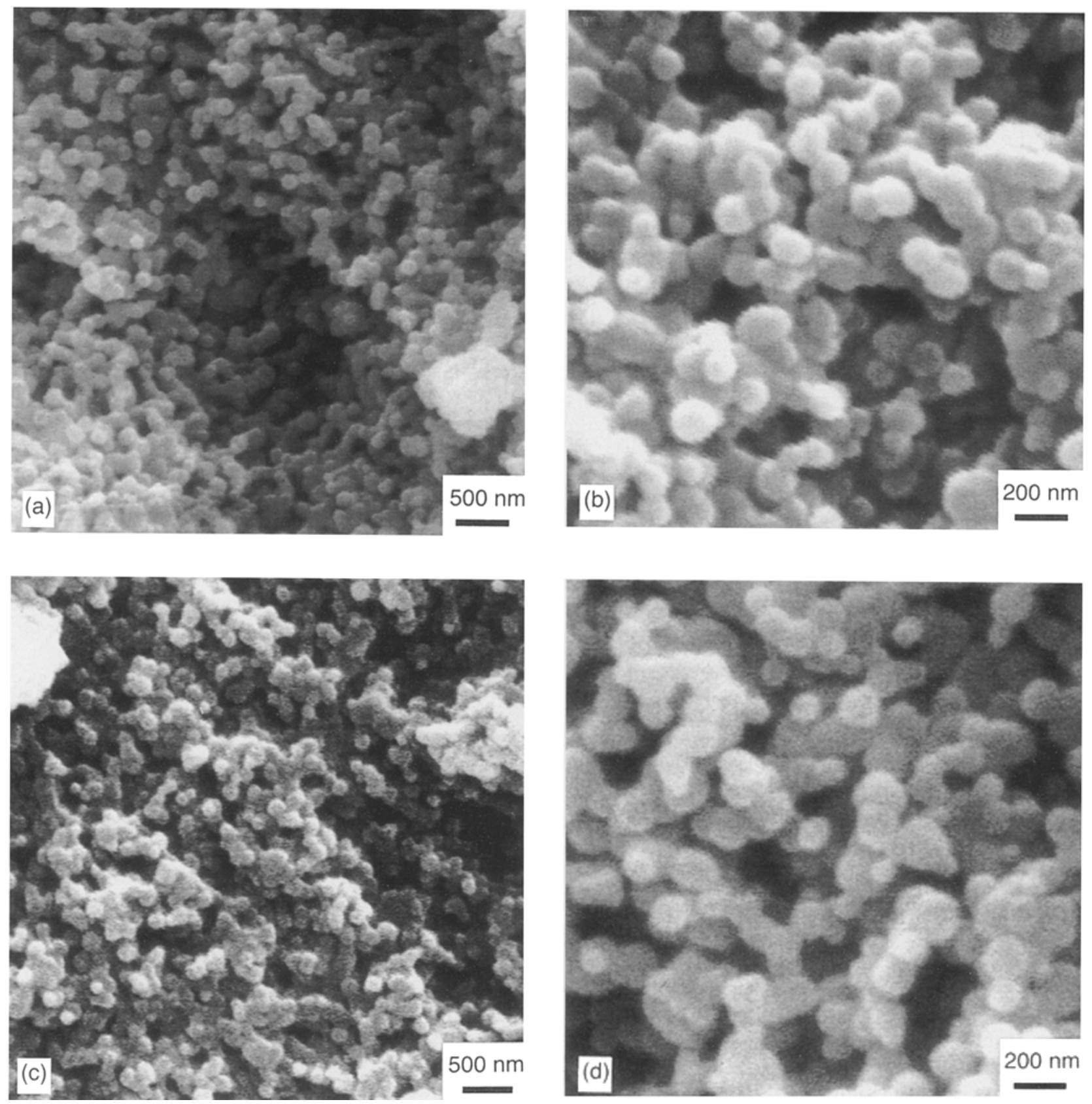

Figure 5 SEM observation of morphology of xerogels zirconia phosphate heat treated at $150{ }^{\circ} \mathrm{C}$ during $2 \mathrm{~h}(\mathrm{a}-\mathrm{b})$ and $400{ }^{\circ} \mathrm{C}$ during $2 \mathrm{~h}(\mathrm{c}-\mathrm{d})$.

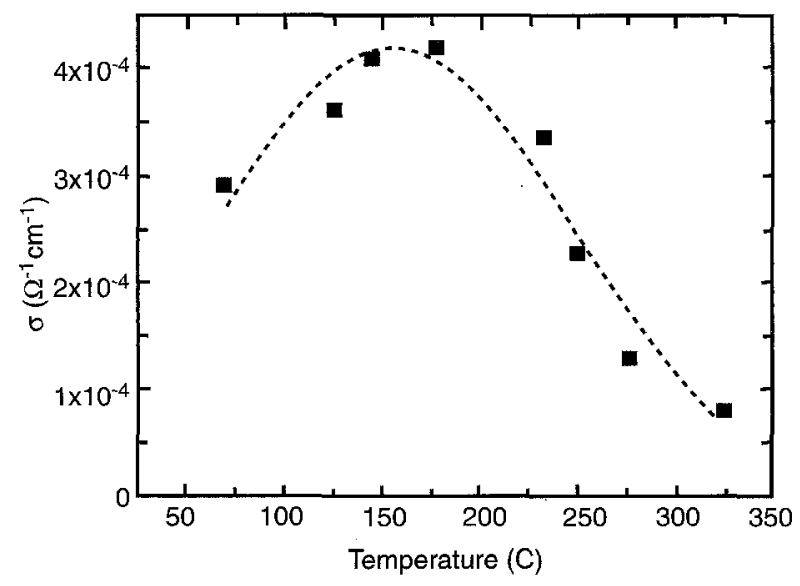

Figure $6 \alpha$ values versus temperature for $\alpha$-ZrP.

\section{References}

1. L. L. HENCH and G. ORCEL, in "Better ceramies through chemistry II," edited by C. J. Brinker, D. E. Clark and D. R. Ulrich (MRS Vol. 73, Pittsburgh, 1986) p.35.

2. M. TOKI, S, MIYASHITA, T. TAKENCHI, S. KANBE and A. KOCHI, J. Non-Cryst. Solids 100 (1988) 479.

3. S. SAKKA and K. KAMIYA, ibid. 42 (1980) 403.

4. H. DISLICH, in "Sol-gel technology for thin films, fibers, preforms, electronics and specialty shapes," edited by L. C. Klein (Noyes, Park Ridge, NJ, 1988), p. 50.

5. R. P. HAMLEN and E. I. SZYMALAK, Electrochem. Technol. 4 (1966) 172.

6. C. BERGER and M. P. STRIER, J. Electrochem. Soc. $\mathbf{1 1 5}$ (1968) 230

7. G. Alberti, M. CASCIOLA, U. COSTANTino and M. LEONARDI, Solid State Ionics 14 (1984) 289.

8. E. KROGH ANDERSEN, I, G. KROGH ANDERSËN, C. KNAKKKERGARD MOLLER, K. E. SIMONSEN and E. SKOU, ibid. 7 (1982), 301. 
9. S. YDE ANDERSEN, J. S. LUNDSGAARD, J. MALLING and J. JENSEN, ibid. 13 (1984) 81.

10. M. ATIK and M. A. AEGERTER, J. Non Cryst. Solids 147 \& 148 (1992) 813.

11. P. DE LIMA NETO, M. ATIK, L. AVACA and M. A. AEGERTER, J. of Sol-Gel Sci. Technol. 1 (1994) 177.

12. M. ATIK, C. R'KHA and J. ZARZYCKI, J. Mater. Sci. Lett. 13 (1994) 266.
13. M. ATIK and J. ZARZYCKI, ibid. 13 (1994) 1301.

14. A. CLEARFIELD, "Inorganic ion exchange materials" (CRC Press, Florida, 1982).

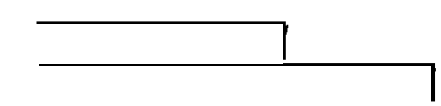

